\title{
INLET AIR FOGGING OF MARINE GAS TURBINE IN POWER OUTPUT LOSS COMPENSATION
}

Zygfryd Domachowski, Prof.

Marek Dzida, Assoc. Prof.

Gdańsk Univeristy of Technology, Poland

\begin{abstract}
The use of inlet air fogging installation to boost the power for gas turbine engines is widely applied in the power generation sector. The application of fogging to mechanical drive is rarely considered in literature [1]. This paper will cover some considerations relating to its application for gas turbines in ship drive.

There is an important evaporative cooling potential throughout the world, when the dynamic data is evaluated, based on an analysis of coincident wet and dry bulb information. This data will allow ships' gas turbine operators to make an assessment of the economics of evaporative fogging. The paper represents an introduction to the methodology and data analysis to derive the direct evaporative cooling potential to be used in marine gas turbine power output loss compensation.
\end{abstract}

Keywords: marine gas turbine; ambient temperature; power output loss compensation; inlet air fogging; methodology

\section{INTRODUCTION}

The gas turbine output as well as efficiency strongly depends on the ambient temperature. For every $1^{\circ} \mathrm{C}$ rise in ambient temperature, a gas turbine output drops by $0,5-0,9 \%$, and a heat rate increases about $0,2 \%$ [2]. The detrimental effect of ambient temperature on gas turbine output and efficiency creates problems for operators of as well power generation and mechanical drive units. In hot and dry air regions, gas turbine power output is dramatically reduced because of the reduction in gas turbine air mass flow. This effect is particularly predominant with aero derivative units that are commonly used in the marine drive, see Fig. 1. Cooling the air to the wet bulb temperature will increase the density of the air, increase the air mass flow, and boost the gas turbine engine power and efficiency.

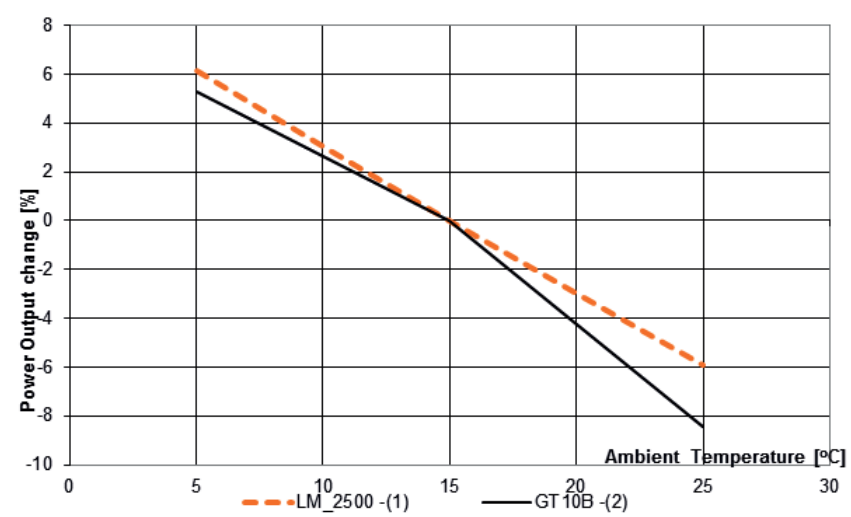

Fig. 1. Typical Temperature - Power Relation for Aero derivative Marine Gas Turbine (Two - Shaft) LM2500 (1) and Electric Power Gas Turbine GT10B (2)
To compensate a gas turbine output loss when ambient temperature rises, several inlet air cooling technologies are available. In such case, a selection of the climatic design point is of principal importance [3]. Then the choice of the gas turbine power augmentation technology depends on the following factors:

- The type of the gas turbine service.

- The cost of the fuel.

- The benefits of power augmentation.

- The variability of climatic conditions.

\section{ELECTRIC POWER GENERATION}

In the electric power generation, the gas turbine output augmentation can impact economics and /or frequency control performance of the electric power gird. Three modes of gas turbine service in the power generation can be distinguished.

- $\quad$ Based load, e.g. combined cycle of large power plants where additional power at any time results in additional revenue.

- $\quad$ Peaking service, where meeting the higher demand enables to satisfy the required frequency performance. In the same time the revenue is much higher than standard.

- $\quad$ Supporting wind power plants, where vagaries of the wind speed need adequate local support from conventional sources to provide limiting of the power and frequency fluctuations [5]. 
The design point for a gas turbine which is planned to be installed very often is the basis of design for the project in some areas. When the application of gas turbine power augmentation technologies such as evaporative cooling or mechanical chilling is assumed, then the selection of the design point is based on the use of locally collected weather data. On such basis, an accurate and appropriate analysis should be developed to compare different cooling technologies taking into account the type of project, the power demand diagram, coincident air temperature and humidity, electricity and fuel prices. Especially in hot arid areas, the cooling approaches are in use for several decades [7].

In specific location of a gas turbine, an analysis of climatic data is necessary to provide the full year sites' temperature profile. This data can be used to generate the so-called cooling "degree hours" [2] which are a measure of available cooling potential. For each hour of the year such an analysis allows a gas turbine operator to evaluate the available power gain from power augmentation. Usually several climatic data sources are available. Most of them are average (typical and representative) weather data. Most frequently, they may provide a sufficient description of an estimated value of the cooling potential in specific location.

\section{POWER AUGUMENTION OF SHIP GAS TURBINE}

The marine gas turbines offer advantages for specific ship categories such as cruise ships, fast ferries, fast cold storage vessels, general refrigerated ships, fruit carriers, packet ships, mega - yachts, naval vessels. All fast ships need prime mover operation at maximum performance parameters. Full power operation at prime mover optimal parameters results in maximum speed of a ship on one hand and environmentally friendly conditions on the other hand. The change of ambient air temperature influences prime mover performance. Voyaging at cold weather (air temperature lower than the design point), the thermal efficiency is improved. Above the design point air temperature, the thermal efficiency of a gas turbine decreases which results in power output decrease. This effect can be more severe on aero derivative engines mostly used in ship drive, Fig. 1.

For ship drive applications, when output power from the gas turbine falls on hot days, very often power output demand is high and the power margins originally designed into the driver have been exhausted. In such circumstances augmenting gas turbine power output can have an important impact on profitability.

\section{AIR TEMPERATURE CHANGE DURING SHIP VOYAGE}

Viewing an air temperature change lets us take into account separately a short, and a long sea voyage of a ship. The Baltic Sea on one hand and the Mediterranean Sea on the other can be considered for a short voyage e.g. of a ferry equipped with gas turbine.
In Fig. 2 and in Fig. 3 the air temperature on the shore of Baltic Sea in January (in winter), and in July (in summer) is represented; Fig. 4 and Fig. 5 - air temperature on the shore of Mediterranean Sea.

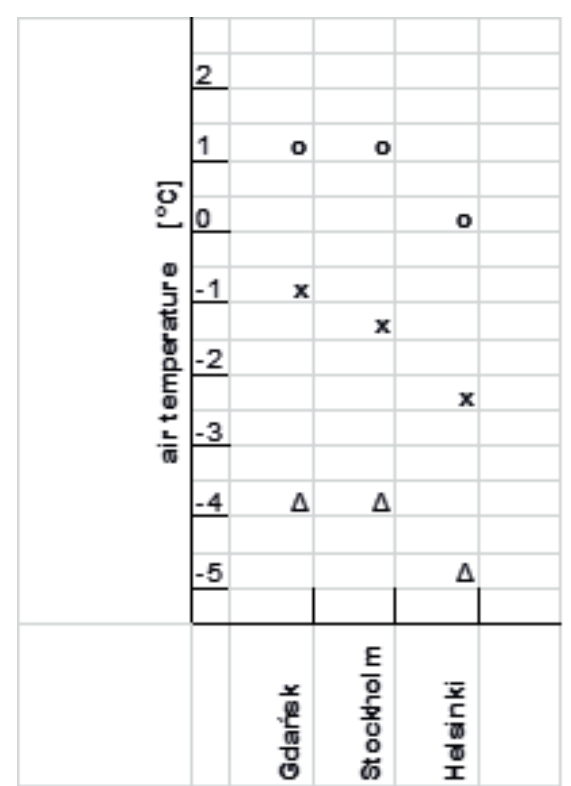

Fig. 2. Air Temperature on the Shore of Baltic Sea in January $o$ - $\max ; x$-average; $\Delta$ - min

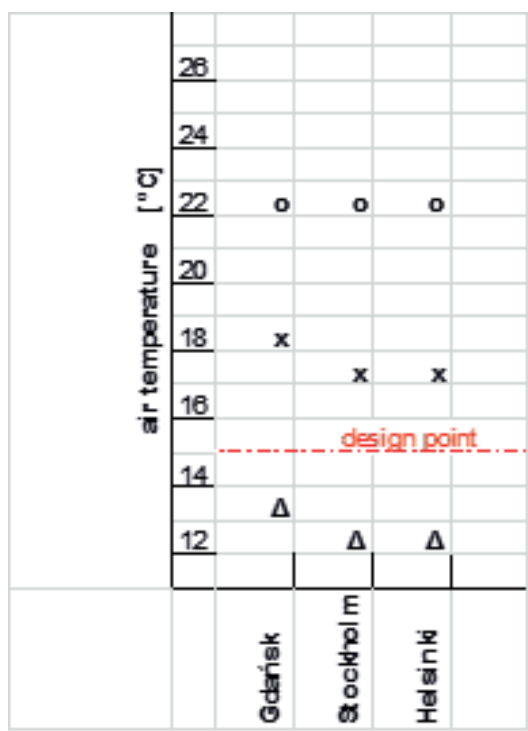

Fig. 3. Air Temperature on the Shore of the Baltic Sea in July $o$ - max; $x$-average; $\Delta$ - min

For a long sea voyage consider e.g. the distance between the Baltic Sea region and the Far East area. Air temperature in several ports on such a way is represented in Fig. 6 (January) and Fig. 7 (July). 


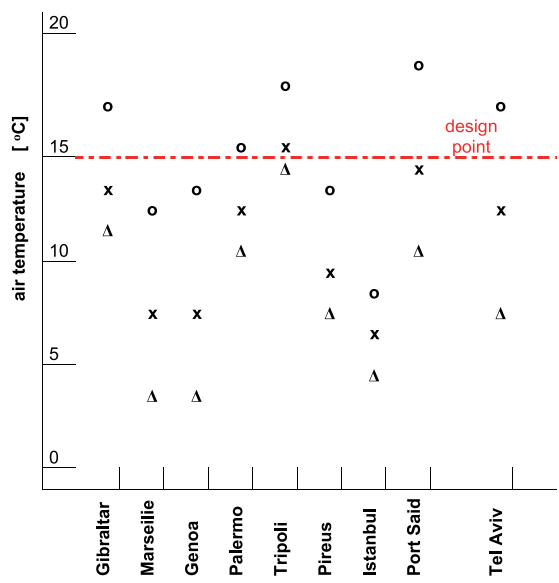

Fig. 4. Air Temperature on the Shore of the Mediterranean Sea in January $o$ - max; $x$-average; $\Delta$ - min

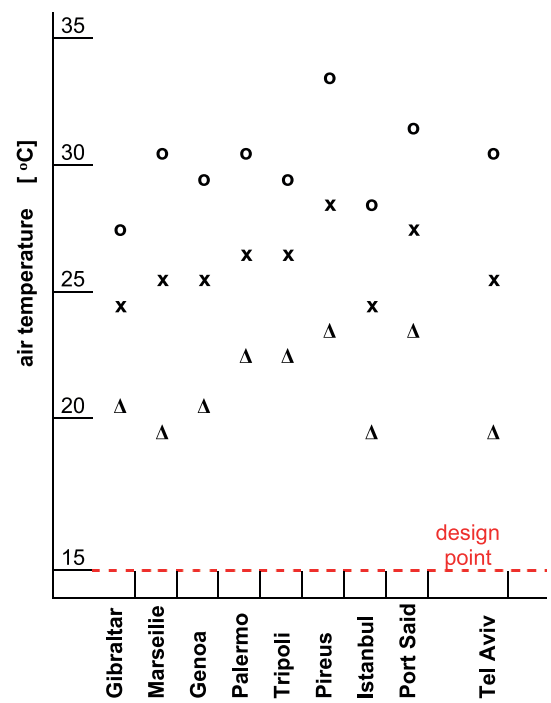

Fig. 5. Air Temperature on the Shore of the Mediterranean Sea in July $o$ - $\max ; x$-average; $\Delta$ - $\min$

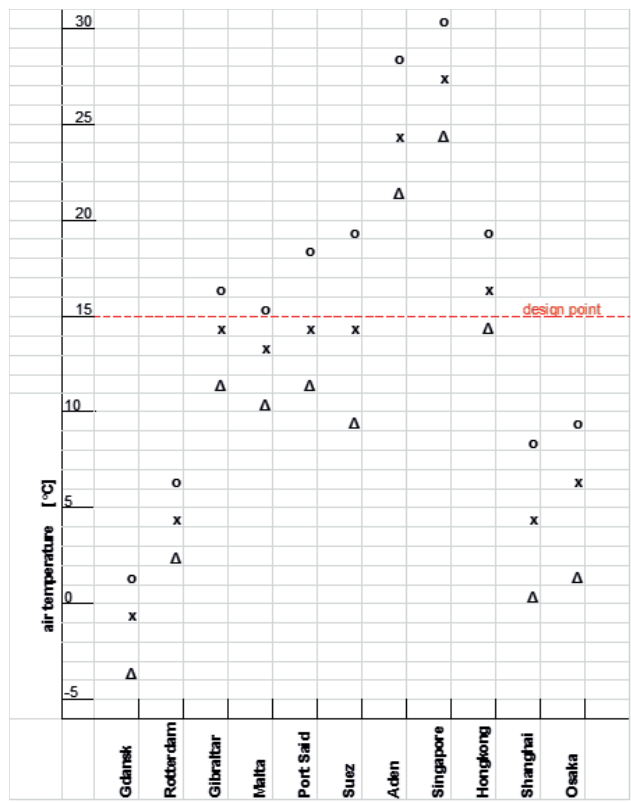

Fig. 6. Air Temperature on the way from the Baltic Sea to Far East Area in January; $o$ - $\max$; $x$ - average; $\Delta$ - $\min$

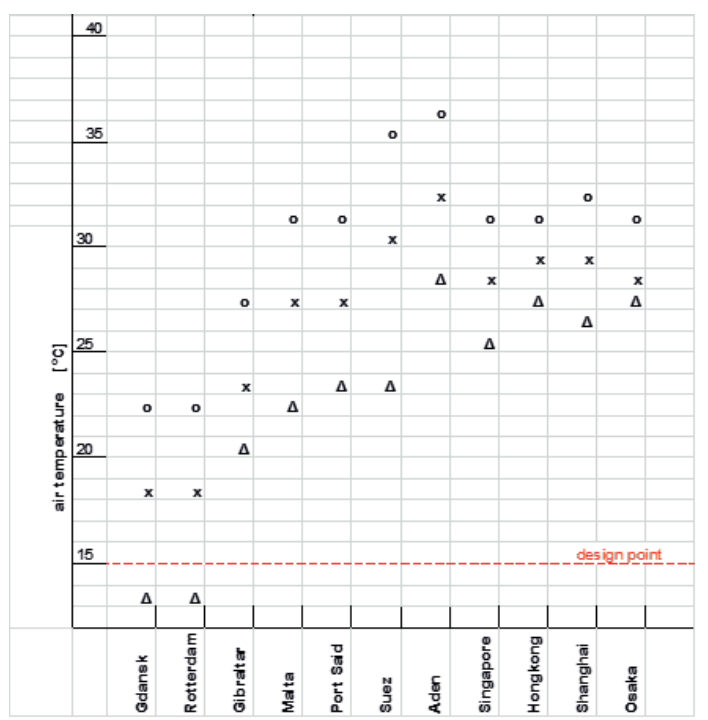

Fig. 7. Air Temperature on the way from the Baltic Sea to far East Area in July $o$ - $\max ; x$-average; $\Delta$ - $\min$

\section{AIR COOLING TECHNOLOGY FOR SHIP GAS TURBINE POWER AUGMENTATION}

The detriment effect of ambient temperature increase on gas turbine output and efficiency poses a significant problem in the ship drive during high demand. In such case, the use of power augmentation can reduce the dependency on ambient temperature. In the ship drive, two cooling technologies can be considered. They are: an evaporative cooling or chilling. Chilling is accomplished mainly by mechanical package chillers. In the ship use, the evaporative cooling seems to prevail over the chilling because of lighter weight and smaller bulk of additional installation.

The basic principle of evaporative cooling consists in latent heat water vaporization. When water evaporates, it cools the air at the gas turbine inlet. The effectiveness of traditional evaporative cooler can be defined as:

$$
E=\frac{T_{D B} \quad T_{D B}}{T_{1 D B}} T_{W B}
$$

where $T_{1}$ is inlet temperature, $T_{2}$ - exit temperature of evaporative cooler, DB - dry bulb, WB - wet bulb. [7]. The wet bulb temperature can never be attained. A typical value for effectiveness is $85-90 \%$. The use of a media type evaporative cooler inherently involves a pressure drop in inlet duct. These drop losses result in a drop in power output and efficiency.

Direct inlet fogging is a method of cooling, where demineralized water is converted into a fog by means of special nozzles operating at $7-14 \mathrm{MPa}$. When compared to other technologies (media evaporative cooling and refrigeration technologies), fogging has seen large-scale application because of low first cost. This technique allows attaining effectiveness close to $100 \%$. That means the relative humidity at the gas turbine inlet will be $100 \%$ which gives the lowest temperature possible (as the wet bulb temperature) without refrigeration. 
Several weather data sources may provide a sufficient description and give an estimated value of the cooling potential in a specific location. The change of location, the change in the climate needs special treatment to quantify the impact of these effects on the weather data and consequently on the efficiency of gas turbine inlet air cooling system. The Equivalent Cooling Degree Hours (ECDH) calculations are a useful measure when inlet fogging is deployed. The cooling degree hours is a number $\left(0^{\mathrm{C}}\right.$ - hours) that defines the total amount of cooling that can be derived in a given time period. The ECDH is calculated with a lower limit of Minimum Wet Bulb Temperature (MWBT) varying between $7,2{ }^{\circ} \mathrm{C}(450 \mathrm{~F})$ and $12,8^{\circ} \mathrm{C}(550 \mathrm{~F})$ [2]. The MWBT is selected in order to avoid the possibility of inlet icing. The ECDH is calculated as the difference between the coincident dry bulb temperature and the wet bulb temperature multiplied by the number of hours that this difference exists if the wet bulb temperature is above the lower limit of MWBT. At a given location the ECDH number would be multiplied by the gas turbine specific $\mathrm{kW} /{ }^{\circ} \mathrm{C}$ cooling number to compute the $\mathrm{kW}$ - hours of capacity available by the use of inlet fogging. For example, if the ECDH is 10000 degree - hours, then a gas turbine such as the LM 2500 which has the specific cooling number of approximately $134,4 \mathrm{~kW} /{ }^{\circ} \mathrm{C}$, see Fig. 1, the $\mathrm{kW}$ - hours gained would be 10000 0C -hrs x $134,4 \mathrm{~kW} /{ }^{\circ} \mathrm{C}=1344000 \mathrm{~kW}-\mathrm{hrs}$.

There is a relatively large evaporative cooling potential throughout the world. It can be evaluated, based on an analysis of coincident wet bulb and dry bulb information when the climatic data is available. In [2] a detailed climatic analysis has been made of 106 major locations over the world to provide the cooling hours that can be obtained by inlet fogging. The source of data was a database published by Airforce Combat Climatology Centre. A cross check was performed with American Society of Heating and Refrigeration Engineers (ASHRE) data. The ECDH was calculated assuming a lower WBT limit of $12,8^{\circ} \mathrm{C}(550 \mathrm{~F})$. This number was considered to avoid any possibility of inlet icing.

\section{EVALUATION EXAMPLE OF THE POTENTIAL POWER GAIN FROM INLET FOGGING ON SHIP'S VOYAGE}

Table 1 shows cooling hours for some ports on the shore of the Baltic Sea, on the shore of Mediterranean Sea, and on the way from Baltic Sea Area to Far East Area. Any operator of ship gas turbine can evaluate the potential for evaporative cooling per month in the region of this ship's location, based on databases such as those in Table 1. Multiplying the ECDH number by the turbine specific $\mathrm{kW} /{ }^{\circ} \mathrm{C}$ cooling number, it is possible to calculate the $\mathrm{kW}$ - hours of capacity available by the use of evaporative fogging.

On the way from Baltic Sea Area to Far East Area, there are regions of high humidity (e.g. Madras, Manila, Hong Kong areas). Therefore, it is worth to remark, that the moisture

- holding capacity of air depends on its temperature. Warmer air can hold more moisture then cooler air. This results in the conclusion, that high relative humidity generally occurs time
- coincident with the lowest temperature and the lowest relative humidity occurs with the highest temperature. Therefore, relative humidity is the highest during the cool morning and evening hours and the lowest in the hot afternoon hours. That's because even in the most humid environments, it is possible for an evaporative cooling up to $80 \mathrm{C}$ during the hotter part of the day. The sites' temperature profile for a full day of hourly data of wet and dry bulb coincident temperatures have to be considered in the analysis. On such basis, evaporative cooling degree hour $(\mathrm{ECDH})$ numbers for each hour of the day can be calculated. These data allow a gas turbine operator to evaluate the potential power gain from inlet fogging.

Tab. 1. Available Monthly and Yearly ECDH in the Baltic Sea Area, the Mediterranean Sea Area, and on the Voyage from Baltic sea Area to Far East Area, Min. WBT $=12,8^{\circ} \mathrm{C}$

\begin{tabular}{|c|c|c|c|c|c|c|c|c|c|c|c|c|c|}
\hline & Jan. & Feb. & Mar. & Apr. & May & Jun. & Jul. & Aug. & Sep. & Oct. & Nov. & Dec. & Ann. \\
\hline \multicolumn{14}{|c|}{ Baltic Sea Area } \\
\hline Stockholm & 0 & 0 & 0 & 22 & 394 & 1189 & 2269 & 1786 & 200 & 10 & 0 & 0 & 5871 \\
\hline \multicolumn{14}{|c|}{ Mediterranean Sea area } \\
\hline Barcelona & 4 & 28 & 80 & 485 & 1361 & 1933 & 2391 & 2337 & 2015 & 1365 & 485 & 62 & 12546 \\
\hline Marseille & 0 & 9 & 98 & 296 & 2158 & 3251 & 4212 & 3909 & 2635 & 1321 & 267 & 35 & 18192 \\
\hline Naples & 24 & 9 & 176 & 728 & 2167 & 2513 & 3050 & 2941 & 2185 & 1535 & 491 & 126 & 15945 \\
\hline $\begin{array}{l}\text { Venezia } \\
\end{array}$ & 0 & 0 & 14 & 313 & 1869 & 2285 & 2802 & 2665 & 1785 & 731 & 44 & 1 & 12508 \\
\hline $\begin{array}{l}\text { Khania } \\
\text { (Crete) }\end{array}$ & 49 & 55 & 213 & 1367 & 3451 & 4887 & 5192 & 4931 & 3848 & 2616 & 1190 & 364 & 28161 \\
\hline Istanbul & 0 & 0 & 013 & 364 & 1776 & 2995 & 3413 & 3270 & 2696 & 1402 & 290 & 0 & 16220 \\
\hline Beirut & 278 & 476 & 1236 & 2397 & 2623 & 2815 & 3062 & 3076 & 3608 & 3552 & 2608 & 988 & 26717 \\
\hline Tel Aviv & 325 & 434 & 1436 & 2708 & 2689 & 2679 & 2846 & 3125 & 3272 & 3280 & 2659 & 997 & 26449 \\
\hline Tripoli & 244 & 620 & 1710 & 3030 & 4602 & 4993 & 5087 & 4954 & 4274 & 3582 & 2103 & 786 & 35984 \\
\hline Tunis & 222 & 283 & 721 & 1348 & 2687 & 3508 & 4216 & 3998 & 3078 & 2240 & 1324 & 541 & 24166 \\
\hline \multicolumn{14}{|c|}{ Voyage from Baltic Sea Area to Far East Area } \\
\hline Stockholm & 0 & 0 & 0 & 22 & 394 & 1189 & 2269 & 1786 & 200 & 10 & 0 & 0 & 5871 \\
\hline Oslo & 0 & 0 & 0 & 11 & 333 & 1300 & 2482 & 2035 & 165 & 1 & 0 & 0 & 6328 \\
\hline Amsterdam & 0 & 0 & 4 & 93 & 686 & 1110 & 1565 & 1675 & 759 & 201 & 9 & 0 & 6104 \\
\hline Lisbon & 110 & 151 & 549 & 992 & 1855 & 2744 & 3542 & 3543 & 2990 & 1745 & 661 & 244 & 19127 \\
\hline Tripoli & 244 & 620 & 1710 & 3030 & 4602 & 4993 & 5087 & 4954 & 4274 & 3582 & 2103 & 786 & 35984 \\
\hline Aleksandria & 602 & 730 & 1336 & 2609 & 3061 & 3043 & 2916 & 3122 & 3266 & 3051 & 2412 & 1313 & 27462 \\
\hline Madras & 2485 & 2497 & 3030 & 3066 & 4177 & 4704 & 3928 & 3645 & 2899 & 2279 & 1937 & 2276 & 36921 \\
\hline Singapore & 1595 & 1498 & 1708 & 1402 & 1439 & 1485 & 1546 & 1632 & 1377 & 1428 & 1040 & 1162 & 17313 \\
\hline Manila & 2462 & 2567 & 3251 & 3378 & 3096 & 2295 & 2008 & 1860 & 1729 & 1908 & 2063 & 2219 & 28836 \\
\hline Hongkong & 1529 & 1299 & 1531 & 1735 & 1945 & 2106 & 2406 & 2447 & 2736 & 3300 & 3004 & 2184 & 26221 \\
\hline Shanghai & 2 & 47 & 109 & 894 & 1991 & 1669 & 1889 & 1938 & 1911 & 1804 & 587 & 54 & 12894 \\
\hline Pusan & 0 & 8 & 8 & 585 & 2025 & 1815 & 1507 & 2041 & 2265 & 1922 & 307 & 10 & 12494 \\
\hline Osaka & 0 & 7 & 38 & 999 & 2681 & 2817 & 2897 & 3389 & 2811 & 2082 & 533 & 16 & 18271 \\
\hline
\end{tabular}

\section{CONTROL SYSTEM OF INLET AIR FOGGING}

A typical inlet air fogging system for gas turbine application consists of a series of high - pressure reciprocating pumps providing demineralized water to an array of fogging nozzles installed in the inlet air duct. Each high - pressure pump is connected to a fixed number of fog nozzles representing one discrete capacity of fog cooling, see Fig. 8. The pumps can be turned on or off sequentially to control the amount of cooling water. 


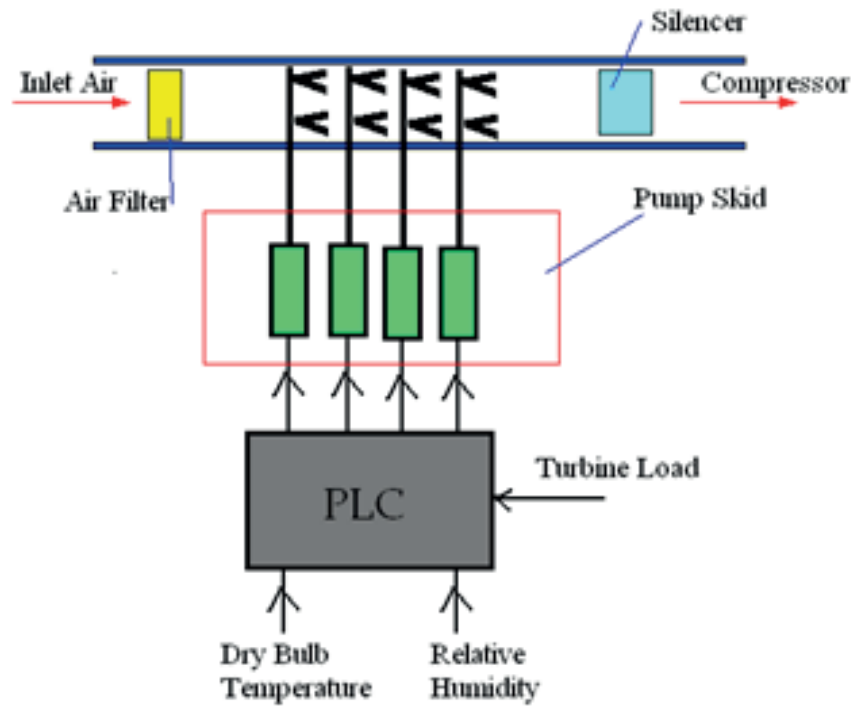

Fig. 8. Gas Turbine Inlet Fogging Control System

Fore chosen pump displacements, it is possible to obtain several cooling stages by the utilization of different pump combinations $[7,8]$. For example, using four pumps, one rated at $0,5 \mathrm{~m}^{3} / \mathrm{h}$ and three at $1 \mathrm{~m}^{3} / \mathrm{h}$, seven cooling stages are possible, see Table 2 .

Tab. 2. Seven cooling stages utilizing one pump at $0,5 \mathrm{~m}^{3} / \mathrm{h}$ and three at 1 $m^{3} / h,+$ mean pump unit "on".

\begin{tabular}{|c|c|c|c|c|c|c|}
\hline \multirow{2}{*}{$\begin{array}{c}\text { Cooling } \\
\text { stage }\end{array}$} & \multicolumn{4}{|c|}{ Pump number } & \multirow{2}{*}{$\begin{array}{l}\text { Flow } \\
\mathrm{m}^{3} / \mathrm{h}\end{array}$} & \multirow{2}{*}{$\begin{array}{c}\text { Cooling } \\
{ }^{\circ} \mathrm{C}\end{array}$} \\
\hline & 1 & 2 & 3 & 4 & & \\
\hline 1 & + & & & & 0,5 & 3 \\
\hline 2 & & + & & & 1,0 & 6 \\
\hline 3 & + & + & & & 1,5 & 9 \\
\hline 4 & & + & + & & 2,0 & 12 \\
\hline 5 & + & + & + & & 2,5 & 15 \\
\hline 6 & & + & + & + & 3,0 & $1 \square$ \\
\hline$\square$ & + & + & + & + & 3,5 & 21 \\
\hline
\end{tabular}

In this example, as the day temperature increases, a $9{ }^{\circ} \mathrm{C}$ drop in temperature may be managed in three cooling increments, see Table 3. Each stage is activated for $30{ }^{\circ} \mathrm{C}$ cooling. Smaller increments would require more stages.

Tab. 3. Example of Fog Cooling Stage Control (Three Stages of $30{ }^{\circ} \mathrm{C}$ Each)

\begin{tabular}{|c|c|c|c|c|c|c|}
\hline Time & $\begin{array}{c}\text { Dry Bulb } \\
\text { Temperature }\end{array}$ & $\begin{array}{c}\text { Wet Bulb } \\
\text { Temperature }\end{array}$ & Depression & $\begin{array}{c}\text { Stage } \\
\text { "on" }\end{array}$ & Cooling & Overcooling \\
\hline $9: 00$ & $21{ }^{0} \mathrm{C}$ & $20^{\circ} \mathrm{C}$ & $1{ }^{0} \mathrm{C}$ & None & & $1{ }^{\circ} \mathrm{C}$ \\
\hline $10: 00$ & $24^{0} \mathrm{C}$ & $20,5^{0} \mathrm{C}$ & $3,5^{\circ} \mathrm{C}$ & 1 & $3{ }^{0} \mathrm{C}$ & $2{ }^{0} \mathrm{C}$ \\
\hline $11: 00$ & $27{ }^{0} \mathrm{C}$ & $21{ }^{\circ} \mathrm{C}$ & $6{ }^{\circ} \mathrm{C}$ & 2 & $6{ }^{\circ} \mathrm{C}$ & $2,5^{\circ} \mathrm{C}$ \\
\hline $12: 00$ & $30^{\circ} \mathrm{C}$ & $21{ }^{\circ} \mathrm{C}$ & $9{ }^{\circ} \mathrm{C}$ & 3 & $9{ }^{\circ} \mathrm{C}$ & $2{ }^{\circ} \mathrm{C}$ \\
\hline
\end{tabular}

The sites' temperature profile for a full day of hourly data of wet bulb and dry bulb temperatures, and by the same of wet temperature depression, depends on the region in the world, on the month, and day. Table 4 shows examples of numbers of ECDHs for which certain wet bulb depression ranges are available in several ports in the voyage from Baltic Sea Area to Far East Area. The ranges are selected in groups of $0-50{ }^{\circ} \mathrm{C}, 10-15{ }^{\circ} \mathrm{C}, 15-200{ }^{\circ} \mathrm{C}$, and $>20{ }^{\circ} \mathrm{C}$. The numbers provide information on the availability of cooling in different regions of the world.

Tab. 4. Availability of ECDH of a Range of $W B D\left({ }^{\circ} C\right)$ in the Voyage from Baltic Sea Area to Far East Area Min. WBT $=12,8^{\circ} \mathrm{C}$

\begin{tabular}{|l|c|c|c|c|c|}
\hline & \multicolumn{5}{|l}{} \\
\hline & $0-5$ & $5-10$ & $10-15$ & $15-20$ & $>20$ \\
\hline Stockholm & 2066 & 3783 & 125 & $0 \rightarrow$ & $0 \rightarrow$ \\
\hline Oslo & 1385 & 4461 & 309 & $0 \rightarrow$ & $0 \rightarrow$ \\
\hline Amsterdam & 4558 & 1600 & 55 & $0 \rightarrow$ & $0 \rightarrow$ \\
\hline Lisbon & 9572 & 8067 & 1943 & 113 & 0 \\
\hline Tripoli & 8311 & 16585 & 8366 & 3148 & 105 \\
\hline Aleksandria & 14453 & 12240 & 380 & 116 & 2 \\
\hline$\square$ adras & 14881 & 17874 & 3495 & 205 & 0 \\
\hline Sin $\square$ apore & 14181 & 4068 & 0 & 0 & 0 \\
\hline$\square$ anila & 20330 & 8247 & 13 & 0 & 0 \\
\hline$\square$ on $\square$ kon $\square$ & 23809 & 2082 & 0 & 0 & 0 \\
\hline Shan $\square$ hai & 10938 & 1906 & 8 & 0 & 0 \\
\hline$\square \square$ san & 11968 & 550 & 0 & 0 & 0 \\
\hline Osaka & 9931 & 8428 & 104 & 0 & 0 \\
\hline & & & & & \\
\hline & & & & & \\
\hline
\end{tabular}

The temperature and humidity sensors are provided to measure ambient relative humidity and dry bulb temperature. These measured parameters are used to compute the ambient wet bulb temperature and the difference between dry bulb and wet bulb temperature (the depression) to calculate and control the amount of evaporative cooling. This is the role of programming algorithms in the Programmable Logic Controller (PLC) mounted on the high - pressure pump skid, see Fig. 8.

To implement inlet fogging, very little modification of the gas turbine, an inlet air system is needed. The most applied location for the high - pressure fog nozzle manifolds is the downstream of the air - filter. This option for installing the inlet fogging allows for moreover fog intercooling. In such, case the control system supplies a greater quantity of water that can be evaporated prior to the compressor inlet. The excess fog is brought into the compressor. This creates a compressor intercooling effect, see the last column in Table 3, which is boosts the gas turbine power output considerably. 
Any marine gas turbine operates at a range of loads. Therefore, the gas turbine load should be an input to the PLC, see Fig.8. The PLC algorithms would then adjust the amount of fog injection in proportion to the inlet air mass flow.

\section{ECONOMIC ASSUMPTION OF INLET AIR FOGGING APPLICATION}

On one hand, to implement inlet fogging, very little modification of the inlet air system is needed. On the other hand the decision to apply inlet air fogging is an economic one. The following factors should be taken into account in a feasibility study:

- Climate profile of a ships' voyage,

- Cost of the cooling system to be installed,

- Amount of MW-h boost gained over a year by means of inlet air cooling, and what benefit is attained as the result of it,

- $\quad$ Parasitic power used, and the effect of increased inlet pressure drop (which is almost nil), and the cost of the demineralized water,

- Projected O\&M costs for the inlet fogging system,

- Potential environmental impact.

\section{CONCLUSION}

In ship drive applications, the gas turbine power output drops on hot days. Very often, power demand is high. In such circumstances augmenting gas turbine power output has an important impact on ship's voyage economics.

The dependency of marine gas turbine on the ambient temperature (power output and efficiency drops with ambient temperature increase) makes inlet air fogging an effective gas turbine power compensation. Power augmentation is a result of water direct evaporation. By this means, the wet bulb temperature is attained at the inlet of compressor. Then, further enhancement of gas turbine power can be attained by fog intercooling. Water excess in form of micron size particles enters compressor. This causes reduction of the gas turbine compressor work.

An investigation has been conducted in order to examine the applicability of inlet air fogging in marine gas turbines. Different areas of ship's voyage have been taken into account. The use of inlet air fogging in marine gas turbines must be evaluated based on the gas turbine characteristics, climate profile of ship's voyage, and expectations of gas turbine power augmentation.

\section{REFERENCES}

1. Al - Amiri, A. M., Zamzam, M.M., Chaker, M.A., Meher - Homji, C. B., "Application of Intel Fogging for Power Augmentation of Mechanical Drive Turbines in the Oil ana Gas Sector", Proceeding of ASME Turbo Expo 2006: Power for Land, Sea and Air, May 8-11, 2006, Barcelona, Spain, ASME Paper GT 2006 - 91054.
2. Chaker, M.A., Meher - Homji, C. B., "Inlet Fogging of Gas Turbine Engines: Climatic Analysis of Gas Turbine Evaporative Cooling Potential of International Locations", Proceedings of ASME Turbo Expo 2002, June 3-6, 2002, Amsterdam, The Netherlands, ASME Paper 2002 - GT 30559.

3. Chaker, M.A., Meher - Homji, C. B., "Selection of Climatic Design Points for Gas Turbine Power Augmentation", Proceedings of ASME Turbo Expo 2011, June 6-10, 2011, Vancouver, British Columbia, Canada, ASME Paper GT2011-46463.

4. Domachowski, Z., "An Impact of Ambient Parameters Change on Steam and Gas Turboset Control", Transactions of the Institute of Fluid - Flow Machinery, No 113, 2003.

5. Domachowski, Z., "Counteracting Windpower Fluctuations within a Separate Electric Power Grid", Proceedings of ASME Turbo Expo 2007: Power for Land, Sea and Air, May 14-17, 2007, Montreal, Canada, ASME Paper GT 2007-28218.

6. Domachowski, Z., Dzida, M., "An Impact of Environmental Disturbances on Combined Cycle Power Plant Control", Proceedings of ASME Turbo Expo 2004: Power for Land, Sea and Air, June 14-17, 2004, Vienna, Austria, ASME Paper GT 2004 - 54057,

7. Meher - Homji, C. B.,Mee, T. R., "Gas Turbine Power Augmentation by Fogging of Inlet Air", Proceedings of the 28th Turbomachinery Symposium, Turbomachinery Laboratory, Texas A\&M University, September 1999, Houston, USA.

8. Meher - Homji, C. B., Mee, T. R., "Intel Fogging of Gas Turbine Engines, part B: Practical Considerations, Control and O\&M Aspects, Proceedings of ASME Turbo Expo 2000, May 8-11, 2000, Munich, Germany, ASME Paper 2000 - GT-308.

\section{CONTACT WITH AUTHOR}

Zygfryd Domachowski Marek Dzida

Gdansk University of Technology Faculty of Ocean Engineering and Ship Technology Narutowicza 11/12 St. 80-288 Gdańsk Poland 